\title{
Risk Assessment of Arsenic Toxicity Through Ground Water-Soil-Rice System in Maldah District, Bengal Delta Basin, India
}

\section{Rubina Khanam}

CRRI: Central Rice Research Institute

Gora Chand Hazra ( $\square$ gchazra@rediffmail.com )

Bidhan Chandra Krishi Viswavidyalaya: Bidhan Chandra Krishi Viswa Vidyalaya

\section{Animesh Gosh Bag}

Bidhan Chandra Krishi Viswavidyalaya: Bidhan Chandra Krishi Viswa Vidyalaya

Nitin Chatterjee

Bidhan Chandra Krishi Viswavidyalaya: Bidhan Chandra Krishi Viswa Vidyalaya

\section{Pedda Ghouse Peera Sheikh Kulsum}

C V Raman Global University

\section{Arvind Kumar Shukla}

Indian Institute of Soil Science

\section{Research Article}

Keywords: Arsenic, Rice, Irrigation water, Inceptisols, Spatial Map, Hazard quotient

Posted Date: May 17th, 2021

DOI: https://doi.org/10.21203/rs.3.rs-508581/v1

License: (9) (i) This work is licensed under a Creative Commons Attribution 4.0 International License. Read Full License 
3

4 Rubina Khanam ${ }^{\mathrm{a}}$, Gora Chand Hazra*b, Animesh Gosh Bag ${ }^{\mathrm{b}}$, Nitin Chatterjee ${ }^{\mathrm{b}}$, Pedda 5 Ghouse Peera Sheikh Kulsum ${ }^{\mathrm{c}}$, Arvind Kumar Shukla ${ }^{\mathrm{d}}$

6

7

8 aICAR-National Rice Research Institute, Cuttack, Odisha-753006, India

9

10

11

12

14

\section{district, Bengal Delta basin, India}

bidhan Chandra Krishi Viswavidyalaya, Mohanpur- 741252, West Bengal, India

${ }^{\mathrm{c}} \mathrm{C}$ V Raman Global University, Bhubaneswar, Odisha, India

${ }^{\mathrm{d} I C A R-I n d i a n}$ Institute of Soil Science, Bhopal, Madhya Pradesh, India Chandra Krishi Viswavidyalaya, Mohanpur- 741252, West Bengal, India,

\section{gchazra@ rediffmail.com}




\section{Abstract:}

Arsenic (As), a toxic trace element, is of great environmental concern due to its presence in soil, water, plant, animal and human continuum. Its high toxicity and increased appearance in the biosphere have triggered public concern. The present study measured arsenic (As) concentrations in soil, groundwater and rice plant samples of five selected blocks of Maldah district, West Bengal, India. Soil, irrigation water and rice plant samples were collected from fields from the selected study areas. The results revealed the presence of As in higher concentrations than the maximum permissible limit of As in irrigation water $\left(0.1 \mathrm{mg} \mathrm{L}^{-1}\right.$ by WHO and Indian standard) in groundwater of Manikchak $\left(0.553 \pm 0.17 \mathrm{mg} \mathrm{L}^{-1}\right.$, Kaliachak III $\left(0.528 \pm 0.20 \mathrm{mg} \mathrm{L}^{-1}\right)$, Kaliachak II $\left(0.449 \pm 0.15 \mathrm{mg} \mathrm{L}^{-1}\right)$, Kaliachak I $\left(0.207 \pm 0.19 \mathrm{mg} \mathrm{L}^{-1}\right)$ The level of As in soil was also found to higher in those four blocks. The As content in rice grain and field is positively correlated with As content in irrigation water. The analysis of As of locally grown rice, showed the presence of its concentration higher than recommended safe level of As in rice by FAO/WHO (0.2 mg Kg-1) in some villages. The data of consumption of rice per day in the survey was used for the measurement of average daily dose and hazard quotient. Kaliachak III, Manikchak and Kaliachak II showed HQ greater than 1 , indicating the possibility of non-carcinogenic health hazard. The study emphasized the severity of As problem in remote areas of West Bengal, India where people consume As tainted rice due to lack of awareness about the As problem and associated health issues.

Key words: Arsenic, Rice, Irrigation water, Inceptisols, Spatial Map, Hazard quotient 
59 Graphical abstract

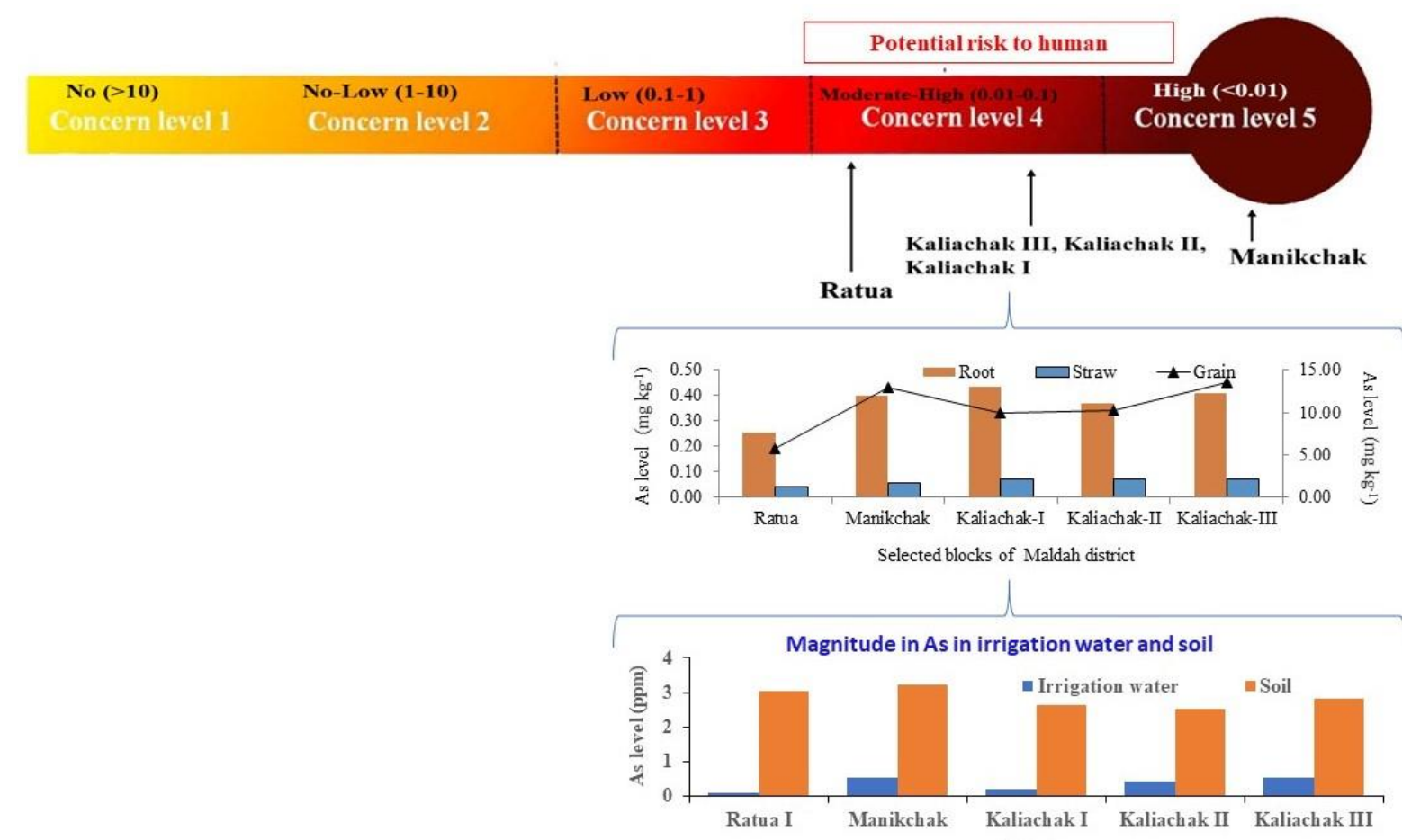

61

62

63

64

65

66

67

68

69

70

71

72

73

74 


\section{Introduction}

The problem of arsenic (As) contamination in irrigation water and loading in edible parts is one of the most alarming factors threatens health risk for more than 150 million people all over the world live in 10 countries in South and South-east Asia: Bangladesh, Cambodia, China, India, Laos, Myanmar, Nepal, Pakistan, Taiwan and Vietnam (Mochizuki, 2019; Nurchi et al., 2020). The occurrence of high As in ground water was first reported in 1978 in West Bengal in India. The most affected areas in West Bengal are on the eastern side of Bhagirathi river in the districts of Maldah, Murshidabad, Nadia, North 24 Parganas and South 24 Parganas and western side of the districts of Howrah, Hooghly and Burdwan. Arsenic contaminated groundwater is used not only for drinking purpose but also for crop irrigation, particularly for the paddy rice (Oryza sativa L.), in south and southeastern Asian countries. In India, As contaminated groundwater has been used extensively to irrigate paddy rice, particularly during the rabi season.

Increasing levels of As in agricultural soils from contaminated underground irrigation water, and its uptake in rice, vegetables, and other food crops (Williams et al., 2006) have become a real health emergency in this region. A number of recent studies report that another major source of As exposure is through the regular consumption of rice cultivated and irrigated with As-contaminated groundwater (Biswas et al., 2020). This is the prime cause of increasing concerns regarding the As content in food, as it is associated with carcinogenicity and a number of multiple adverse health consequences. In human, common symptoms of chronic As toxicity are pigmentation and keratosis. Apart from these symptoms, arsenicosis produces problems such as weakness, chronic respiratory disease, peripheral neuropathy, liver fibrosis, genotoxic effects, cardiovascular diseases, peripheral vascular disease, conjunctivitis, cardiovascular diseases, gangrene and skin cancer, pre-malignant skin lesions, bladder and lung cancer (Khanam et al., 2020). WHO confirmed the maximum permissible limit for 
irrigation purpose is $0.05 \mathrm{mg} \mathrm{L}^{-1}$, for rice as $1 \mathrm{mg} \mathrm{kg}^{-1}$ (Golui et al., 2017), while it is 0.15 and $0.5 \mathrm{mg} \mathrm{kg}^{-1}$ as prescribed by USDA and EU, respectively (Meharg and Zhao, 2012).

In West Bengal, rice is grown traditionally in the monsoon season (July-October) as 'aman or kharif rice' and during the winter season (January-April) as 'boro or summer rice'. Usually the aman rice is rainfed, while the boro rice is irrigated mainly with groundwater. During our investigation, we interviewed farmers of the study area and learnt that they were irrigating their rice fields with arsenic-contaminated groundwater over the past few decades, especially during winter season, as there was very little rainfall received, which led to more As contamination in soils as well as rice plants. Thus, to minimize the knowledge gap about As contamination and determine the potential health threat for local residents, the need was felt to investigate the level of As in different varieties of rice grown using groundwater-based

111 irrigation.

\section{Materials and Methods:}

\subsection{Study area}

114 Maldah district is situated between the Latitude and Longitude of $24^{0} 40^{\prime} 20^{\prime \prime} \mathrm{N}$ to $25^{0}$ $11532^{\prime} 08^{\prime \prime} \mathrm{N}$ and $88^{\circ} 28^{\prime} 10^{\prime \prime} \mathrm{E}$ to $87^{0} 45^{\prime} 50^{\prime \prime} \mathrm{E}$ respectively. The present study was confined to five blocks (Kaliachak-1, Kaliachak I, Kaliachak III, Manikchak and Ratua I) of the district. The study area forms part of the Ganga-Brahmaputra delta comprising quaternary sediments deposited by the Ganga-Pagla-Bhagirathi-Mahananda river system situated just adjacent to the west of Bangladesh, where incidence of elevated As has been reported (Purkait and Mukherjee, 2006).

\subsection{Sample collection}

122 From each block, 20 locations were selected using a hand-held GPS (Garmin GPS 12) for 123 collection of water, soil and rice plants. Water samples were collected directly from irrigation 
sources used for irrigating the rice field. Surface soil $(0-20 \mathrm{~cm})$, irrigation water and rice

plant samples were collected from same location of each selected blocks. As a part of present investigation, 20 samples each of soil, irrigation water and rice plants were collected from same location from each of five selected blocks of each of this district during rabi season. The collected soils and water samples were analysed for a few important properties viz., $\mathrm{pH}$, EC and organic carbon (only for soil).

\subsection{Processing and analysis of samples}

The collected soil samples were dried in a shade on the clean paper, ground in wooden mortar and sieved through $2 \mathrm{~mm}$ nylon sieve. The soil samples were analysed for physic-chemical properties such as mechanical analysis, $\mathrm{pH}, \mathrm{EC}$, organic carbon and available arsenic by standard methods. The collected water samples were kept in $50 \mathrm{~mL}$ sized plastic container with 2-3 drops of diluted $\mathrm{HCl}$ in it to preserve the sample for long use. The samples were filtered through Whatman filter paper 1 and ready for analysis of total arsenic content by standard method. The fresh plants were washed with clean de-ionised water to remove dust and other adhering substances. Then the washed plants samples were dried in the hot air oven at $60^{\circ} \mathrm{C}$ temperatures till constant weight is achieved. The dried plant samples were separated into 3 parts i.e. roots, shoots and grains. The samples were stored properly for determining nutrient/pollutant concentration.

\subsection{Sample digestion and instrumental measurement}

Digestion of the rice and soil samples for As analysis was carried out employing the method used by Rahman et al. (2007) i.e. approximately $0.5 \mathrm{~g}$ ground sample were weighed directly into a $75 \mathrm{~mL}$ digestion tube and $5 \mathrm{~mL}$ concentrated $\mathrm{HNO}_{3}$ was added to it. The mixture was then allowed to stand overnight under fume hood. In the following day, the digestion tubes were heated using temperature-controlled digestion block up to $90^{\circ} \mathrm{C}$. On cooling the tubes, 2 
$\mathrm{mL}$ concentrated perchloric acid was added for plant samples, while for soil additional $3 \mathrm{~mL}$ sulfuric acid was added. Again, the tubes were heated at $160^{\circ} \mathrm{C}$ for about 4 hours; after cooling, the digests were diluted, filtered, and stored in polyethylene bottles for future use.

151 Arsenic in the samples was measured with hydride generation atomic absorption 152 spectrometry (HS-AAS). For hydride generation, analytical standard sodium borohydride 153 (3\%; Merck), sodium hydroxide (2.5\%; Merck) and hydrochloric acid (6 M; Merck) were used. The concentrations detected in all the samples analyzed were above the instrumental limits of detection $(0.2 \mathrm{ppb})$. All glassware and plastic bottles were washed by deionizeddistilled water and dried. The precision of the analysis was always checked by certified standard reference materials (SRMs) (NIST, USA) such as 1568a (rice flour). The analytical results indicated that the observed values were very close to the certified values. Quality control tests were also performed by analyzing triplicates and calculating recovery of spiked digested samples following Rahman et al., 2013.

\subsection{Indices for arsenic transfer and risk assessment}

\subsubsection{Bioaccumulation factor (BAF)}

The $\mathrm{BAF}$ is the ratio of the concentration of As in the plant parts to that in the corresponding soil (Arumugam et al., 2018). It was calculated by the equation:

$\mathrm{BAF}=\frac{\text { Concentration of As in rice root }}{\text { Concentration of As in soil }}$

\subsubsection{Translocation factor $(\mathrm{TF})$}

The TF was calculated to determine relative translocation of As from roots to other parts (shoot or grain) of rice plant as follows (Arumugam et al., 2018):

169 TF root to shoot $($ TFr-s $)=\frac{\text { Concentration of As in rice shoot }}{\text { Concentration of As in rice root }}$

$170 \mathrm{TF}$ shoot to grain $(\mathrm{TFs}-\mathrm{g})=\frac{\text { Concentration of } \text { As in rice grain }}{\text { Concentration of } \text { As in rice shoot }}$

\subsubsection{Average daily intake (ADI)}


Ingestion exposure to As from rice was estimated by calculating Average Daily Intake (ADI) using the following equation; the values were then used to calculate non- carcinogenic risk.

$$
\mathrm{ADI}=\frac{\operatorname{CiAsXIR}}{B W} \times \frac{E F x E D}{A T},
$$

Where, ADI represents average daily intake of As $\left(\mu \mathrm{g}\right.$ day $\left.^{-1}\right)$, CiAs is the concentration of inorganic As [ $\mu \mathrm{g} \mathrm{kg}^{-1}$, taking $86 \%$ of total as inorganic (Halder et al., 2014)], IR is the ingestion rate $\left(\mathrm{kg} \mathrm{day}^{-1}\right) ; \mathrm{BW}$ is body weight $(\mathrm{kg}), \mathrm{EF}$ is the exposure frequency $\left(\mathrm{d} \mathrm{yr}^{-1}\right), \mathrm{ED}$ is the exposure duration (yr) and AT is the averaging time (day) (US EPA, 2011).

\subsubsection{Hazard quotient (HQ)}

The hazard quotient (HQ) was calculated to estimate chronic-toxic risk using the equation:

$\mathrm{HQ}=\frac{A D I}{R f d}$, where, Rfd is the reference dose $0.3 \mu \mathrm{g} \mathrm{kg}^{-1} \mathrm{~d}^{-1}$ (US EPA, 2011).

\subsubsection{Risk thermometer}

Arsenic toxicity exposure level was assessed through risk thermometer taking into consideration the As intake value calculated from the daily consumption of rice. Assessment of risk factor was performed based on As concentration of polished rice, cooking water, and cooked rice prepared through different methods. According to the Swedish National Food Agency, risk thermometer is known for demonstrating new protocol on risk characterization (Sand et al., 2015). The risk thermometer mainly estimates the exposure to a toxic material in food which is compared with the material's health-based reference value (Tolerable Daily Intake, TDI). The different exposure levels to the populations through the ingestion of rice of different cultivars were determined using the following equation as mentioned in other studies (Chowdhury et al., 2020; Sand et al., 2015).

SAMOE (Severity Adjusted Margin of Exposure) $=$ TDI $/\left(\mathrm{AF}_{\mathrm{BMR}} * \mathrm{AF} * \mathrm{SF} * \mathbf{E}\right)$

Where, TDI (Tolerable Daily Intake) $=3.0 \mu \mathrm{g} \mathrm{kg}^{-1} \mathrm{bw}^{-1} \mathrm{day}^{-1}$ value for intake of inorganic As (WHO 2011) 
$\mathrm{AF}_{\mathrm{BMR}}=$ Non-linear relation in dose range $(1 / 10 ; \mathrm{BMR}-$ Benchmark response $)$

$\mathrm{AF}($ Assessment factors $)=\mathrm{A}$ factor 10 (conservative assessment) $($ Sand et al., 2015)

$\mathrm{SF}$ (Severity factor $)=100$ (For cancer, the most severe category)

$E=$ Different exposure factor

\section{Result and discussion}

\subsection{Initial properties of soil and irrigation water of the study area}

202

203

204

205

206

207

208

209

210

211

212

213

214

215

216

217

218

219

220

Soil $\mathrm{pH}$ of the soils of blocks of Maldah Districts ranged from $6.45 \pm 0.663-6.88 \pm 0.277$. Irrigation water also showed slightly alkaline to neutral reaction $(7.3 \pm 0.003-7.9 \pm 0.061)$.

Organic carbon status of the study district was medium to high (Table1) ranged from $0.57 \pm$ $0.172 \%-1.12 \pm 0.129 \%$. Data presented (Table1) showed that the $\mathrm{pH}$ and EC of the water varied from $6.4 \pm 0.012$ to $7.9 \pm 0.061$ and $0.45 \pm 0.09\left(\mathrm{dS} \mathrm{m}^{-1}\right)$ to $\left.1.2 \pm 0.05(\mathrm{dS} \mathrm{m})^{-1}\right)$ respectively. Results, therefore, showed that irrigation water here mostly non-saline in nature and neutral to slightly alkaline in reaction.

\subsection{Spatial distribution of arsenic in irrigation water}

We have analyzed irrigation water contamination by As in the selected blocks and the result was summarized in Table 2. In Manikchak, Kaliachak III, Kaliachak II, KaliachakI andRatua I the percentages of water samples having $>0.05 \mathrm{mg} \mathrm{L}^{-1} \mathrm{As}$ was high and corresponded to $70 \%, 65 \%, 65 \%, 60 \%$, and $45 \%$, respectively. Similar trend was observed with respect to the mean concentration of As in Irrigation water, where Manikchak, Kaliachak III, Kaliachak II, Kaliachak I and Ratua I showed $0.553 \pm 0.17 \mathrm{mg} \mathrm{L}^{-1}, 0.528 \pm 0.20 \mathrm{mg} \mathrm{L}^{-1}, 0.449 \pm 0.15 \mathrm{mg}$ $\mathrm{L}^{-1}, 0.207 \pm 0.19 \mathrm{mg} \mathrm{L}^{-1}$ and $0.093 \pm 0.10$, respectively.

In a report by Kunar et al. (2009) the maximum As concentration in ground water was reported for Manikchak, Kaliachak III, Kaliachak II, Kaliachak I and Ratua I was 0.94 mg L' 1, $0.04 \mathrm{mg} \mathrm{L}^{-1}, 0.91 \mathrm{mg} \mathrm{L}^{-1}, 0.74 \mathrm{mg} \mathrm{L}^{-1}$ and $0.89 \mathrm{mg} \mathrm{L}^{-1}$, respectively. These finding was in good agreement with our result. Our results also corroborated well with the study by 
Rahaman et al. (2011), they showed the As contamination level in water was in the order of Manikchak $\left(0.851 \mathrm{mg} \mathrm{L}^{-1}\right)>$ Kaliachak II $\left(0.793 \mathrm{mg} \mathrm{L}^{-1}\right)>$ Ratua I $\left(0.746 \mathrm{mgL}^{-1}\right)>$ Kaliachak

224

I showed less As contamination in irrigation water with mean concentration of $0.093 \mathrm{mg} \mathrm{L}^{-1}$.

In a previous study by Golui et al. (2017) the As contamination level in irrigation water was found in the order of $0.57 \mathrm{mg} \mathrm{L}^{-1}($ Kaliachak III, $\mathrm{n}=4)$ and $0.48 \mathrm{mg} \mathrm{L}^{-1}$ (Kaliachak II, $\mathrm{n}=5$ ) in Maldah district. The high concentration of As in irrigation water in these area is mainly due to its regional geomorphic set-up. Geomorphologically, the area comprises active flood plain, Older flood plain and the oldest flood plain. The recent flood plain deposits of district, however, recorded high concentration of groundwater As (Goswami, 1995).

\subsection{Spatial distribution of arsenic in soil}

The concentrations of As in the 20 agricultural soils, collected from each above mentioned five blocks, varied widely. Mean As content in soils followed the order was Maniakchak $\left(3.24 \pm 0.808 \mathrm{mg} \mathrm{kg}^{-1}\right)>\operatorname{Ratua}\left(3.03 \pm 0.03 \mathrm{mg} \mathrm{kg}^{-1}\right)>$ Kaliachak III $\left(2.81 \pm 0.283 \mathrm{mg} \mathrm{kg}^{-1}\right)$ $>$ Kaliachak II $\left(2.54 \pm 0.973 \mathrm{mg} \mathrm{kg}^{-1}\right)>$ Kaliachak I (2.64 $\left.\pm 0.0216 \mathrm{mg} \mathrm{kg}^{-1}\right)$ (Table 2). Rahaman et al,2012, on the other hand, reported a higher value of As in soils of the aforesaid five blocks of this district where As concentration in soil was $13.12 \mathrm{mg} \mathrm{kg}^{-1}$ crossed the global average $\left(10.0 \mathrm{mg} \mathrm{kg}^{-1}\right)$, but within the maximum acceptable limit for agricultural soil (20.0 $\mathrm{mg} \mathrm{kg}{ }^{-1}$ ) recommended by the European Union. Purkait and Mukherjee (2006) reported that the high accumulation of As is common in this alluvial track of the Bengal Basin, because of Himalayan erosion, supplying immature sediments with low surface loadings of $\mathrm{FeOOH}$ on mineral, that may release arsenic into soil- water system through changing redox state of aquifer (Nickson et al., 2000; Smedley and Kinniburgh 2002) during heavy pumping of groundwater for agricultural purposes.

\subsection{Arsenic profiling in different plant parts of rice}


246 Rice is being grown in flooded (reduced) conditions, which greatly influences As

247 bioavailability in soil, enabling rice to become more efficient at assimilating As into grain than the dry land cereal crops (Xu et al., 2008). As content root found highest in Kaliachak I $\left(13.03 \pm 8.08 \mathrm{mg} \mathrm{kg}^{-1}\right)$ followed by Kaliachak III $\left(12.22 \pm 5.81 \mathrm{mg} \mathrm{kg}^{-1}\right)$ (Fig.1).

The level of As contamination in rice grain varied from $0.028-0.79 \mathrm{mg} \mathrm{kg}^{-1}$ among the blocks.

The As contamination level in rice grain followed the order of Kaliachak III $\left(0.45 \mathrm{mg} \mathrm{kg}^{-1}\right)$ $>$ Manikchak $\left(0.43 \mathrm{mg} \mathrm{kg}^{-1}\right)>$ Kaliachak III $\left(0.34 \mathrm{mg} \mathrm{kg}^{-1}\right)>$ Kaliachak II $\left(0.34 \mathrm{mg} \mathrm{kg} \mathrm{kg}^{-1}\right)$ >Kaliachak I $\left(0.33 \mathrm{mg} \quad \mathrm{kg}^{-1}\right)$ > Ratua $\mathrm{I} \quad\left(0.23 \mathrm{mg} \quad \mathrm{kg}^{-1}\right)$. In a previous report Rahman et al. (2007) showed As concentration in rice grain collected from Maldah district was $0.429 \mathrm{mg} \mathrm{kg}^{-1}$. The result of the current study and previously reported work had shown that the plant grown in As rich soil and irrigated with As contaminated water deposited As in the tissues (Duxbury et al., 2003).

Irrespective of blocks As accumulation in the edible parts of most of the plants were generally low as compared to root and straw. The accumulation of As in the grain collected from all the blocks did not exceed the WHO permissible limit $\left(1.0 \mathrm{mg} \mathrm{kg}^{-1}\right)$. However, it may contribute to significant exposure to a person having rice-based subsistence diet (Williams et al. 2005).

\subsection{Spatial distribution map of arsenic in irrigation water and soil of Maldah}

Interpolated maps of irrigation water and soil As prepared using Kriging method are presented in Fig 4.20 and 4.21. In case of irrigation water in Manikchak most of the area came under dark colour which meant to be extremely affected $\left(0.5-1.0 \mathrm{mg} \mathrm{L}^{-1}\right)$ category. In Kaliachak III, Kaliachak II and Kaliachak I As concentration in water was not consistent throughout the study area rather, As concentration occurred in patches spread over the study area. Whereas, in Ratua I more than $80 \%$ area fell under moderately affected (0.051-0.10 mg 
271 Kaliachak I showed high spatial variability even in small distance. But in Ratua block map 272 showed lighter colour which represented lower level of As concentration in soil (2.51-5.0 mg $273 \mathrm{~kg}^{-1}$ class $)$.

274 3.6 Relationships between As contents of rice plants, irrigation water and soil parameters

276 The correlation study among As concentrations in irrigation water, soil and in different parts 277 (root, straw and grain) of the rice plant cultivated in the five blocks of the district is presented in table 2 and supplementary Fig.2. The data revealed that there is significant positive correlation among As concentrations in irrigation water, soil, root and grain. Continued irrigation with high As content irrigation water gradually enhance As loading in soil, which further increase its accumulation in different parts of plant (Sanyal et al., 2015). In rice, the bioavailability of As depends on several physical and chemical factors of the soil and/or Irrigation water. Correlation coefficients ( $\mathrm{r}$ ) among arsenic concentrations and in different parts (root, straw, husk, and grain) of the rice plant and selected soil properties ( $\mathrm{pH}$ and organic carbon) summarized in Table 3. Organic carbon showed negative correlation with As accumulation in soil and rice plant parts. Researchers established that there is a growing affinity between iron and manganese oxides and As content in soil (Guo et al., 1997). In the present investigation As concentration soil showed positive co relation with soil $\mathrm{pH}$. Whereas, As concentration in rice grain and straw remain unaffected by soil $\mathrm{pH}$.

\subsection{Bioaccumulation Factor (BAF)}

In order to reflect As transfer from soil to straw and grain in rice in different blocks of Maldah district, BAF for both straw and grain was for each sample and summarized in Table

3. The average BAF soil to root were found to be in the order of Manikchak (3.11) = Ratua I (3.11) > Kaliachak I (2.55) > Kaliachak III (1.68) > Kaliachak II (1.49). Among the blocks, 
BAF values of straw were found in Manikchak (0.19). Data presented in Table 3 revealed

297 that the BAF for grain in Ratua I, Manikchak, Kaliachak I, Kaliachak II and Kaliachak III were $0.05,0.05,0.07,0.05$ and 0.06 , respectively. The lowest BAF both in straw and grain was found in Manikchak block. It indicates that there is strong absorptive capacity of Manikchak block soil to restrict As entry to the plant. The result of the present study showed good agreement with a previous experiment by Singh et al. (2011). They reported As BAF in grain was low (0.04) though the soil was having high As contamination.It is important to note that BAF factor for straw and grain for all the blocks lower than 1.

\subsection{Translocation factor of soil, root and straw}

The calculated TF from root to straw and straw to grain for the studied blocks were present in Table3. However, maximum $\mathrm{TF}_{\text {root }}$ values were seen in Kaliachak II (0.26) and minimum were in Ratua I (0.12) blocks. $\mathrm{TF}_{\text {straw }}$ were found in the following order: Manikchak $(0.27)$ $>$ Kaliachak III (0.25) > Kaliachak II (0.19) > Ratua I (0.18) > Kaliachak I (0.16).

\subsection{Hazard quotient (HQ)}

To evaluate the potential risk of As from contaminated rice consumption to human health through hazardous quotient was calculated for all the selected blocks of the studied district. Result confirmed that HQ value through consumption of rice was $1.36 \pm 0.236$ in Kaliachak III and $1.28 \pm 0.673$ in Manikachak. Likewise, in Kaliachak II, Kaliachak and Ratua I blocks As concentration of irrigation water ranged from $1.01 \pm 0.293,1 \pm 0.304$ and $0.58 \pm 0.586$, respectively (Fig.5). If the Hazard Quotient (HQ) is calculated to be less than 1, then no adverse health effects are expected as a result of exposure. If the Hazard Quotient (HQ) is greater than 1, then adverse health effects are possible. Data derived from this study explained that Manikchak, Kaliachak III, Kaliachak II and Kaliachak blocks has the possibility of non cargenogenic health hazard. Golui et al., 2017 conducted an epidemiology study in Maldah district where they showed hazardous risk to the population through As 
contaminated drinking water and rice diet. It is evident from the range of HQ values from their study that HQ for rice grain, grown in the participants' fields exceeded 1.0 in several cases. On an average, the value of HQ was unacceptable for drinking water indicating that by and large drinking water of the region was unfit for consumption.

\subsection{Risk thermometer for As toxicity}

The 'Risk thermometer' and the calculated Severity Adjusted Margin of Exposure' (SAMOE) value for As toxicity of different rice cultivars cooked in contaminated and noncontaminated water is presented in Supplementary Table 1 and Fig 6. According to this thermometer, consumption of locally grown rice from the selected block were showed separate concern levels of risk from class 4 to class 5 depending on its As concentration. The Manikchak block showed concern level with highest risk (class 5), whereas for Kaliachak III, Kaliachak II and Kaliachak I showed moderate to high risk (class 4), Although, Ratua I fall in class 4 but the SAMOE value is higher than other three blocks of these group. Thus, Ratua I considered to be comparatively at lower risk.

\section{Conclusion}

In the present study, spatial distribution of As was investigated in details in selected blocks of Maldah districts of West Bengal. However, spatially geo-referenced database of As of all the districts of West Bengal is highly anticipated to assess the toxicity problem from all the other parts of the state. High variability of As content in irrigation water and soil was observed in Maldah district. Manikchak recorded the highest soil and irrigation water contamination. Grain As content found highest in Kaliachak III. Ratua 1 recorded lowest As in irrigation water, soil and grain. The use of arsenic-contaminated groundwater for irrigation resulted in elevated As levels in top soils leading to the risk of the arsenic accumulation in locally grown rice and subsequently entering into the food chain. Therefore, rice has been identified as a potentially important route of As exposure. In addition, As accumulation in rice is recognized 

as a disaster for southeast Asia, where rice is a staple food. Remediation aimed at reducing

347 human exposure to rice arsenic in West Bengal should gradually being focused.

348

349

350

351

352

353

354

355

356

357 Not applicable.

358

359

360

361

362

363

364

365

366

367

368

369

370

371

372

\section{Ethics approval}

07

\section{Authors' Contributions}

RK had done the field experiments and the laboratory analyses. GCH conceptualized the study and finalized the methodologies. PGPSK had done statistical analysis of the data. RK and PGPSK prepared the first draft. All authors subsequently added their inputs and improved the MS. GCH had done the overall supervision of the entire research study, manuscript revisions and corrections.

\section{Conflicts of interest}

The authors have no conflict of interest.

\section{Consent to Participate}

All authors informed consent to participate in this paper.

\section{Consent to Publish}

All authors informed consent to publish this paper.

\section{Acknowledgements}

Authors acknowledge the support of All India coordinated Research project (AICRP) on Micro and Secondary nutrients and pollutant elements in soils and plants for providing necessary facilities for execution of this study. 
374 Biswas JK, Warke M, Datta R, Sarkar D. (2020). Is Arsenic in Rice a Major Human Health 375 Concern?. Current Pollution Reports, 6(2), 37-42.

376 Duxbury, J. M., Mayer, A. B., Lauren, J. G., \& Hassan, N. (2003). Food chain aspects of 377 arsenic contamination in Bangladesh: effects on quality and productivity of rice. Journal of 378 Environmental Science and Health, Part A, 38(1), 61-69.

379 Golui, D., Mazumder, D. N. G., Sanyal, S. K., Datta, S. P., Ray, P., Patra, P. K., 380 Bhattacharya, K. (2017). Safe limit of arsenic in soil in relation to dietary exposure of 381 arsenicosis patients from Malda district, West Bengal-A case study. Ecotoxicology and 382 Environmental Safety, 144, 227-235.

Guo, T., DeLaune, R. D., \& Patrick Jr, W. H. (1997). The influence of sediment redox chemistry on chemically active forms of arsenic, cadmium, chromium, and zinc in estuarine sediment. Environment International, 23(3), 305-316.

IRIS. (2017). Integrated Risk Information System-database. US Environmental Protection 387 Agency.

Khanam, R., Kumar, A., Nayak, A. K., Shahid, M., Tripathi, R., Vijayakumar, S. and Chatterjee, D. (2020). Metal (loid) s (As, $\mathrm{Hg}, \mathrm{Se}, \mathrm{Pb}$ and $\mathrm{Cd}$ ) in paddy soil: Bioavailability and potential risk to human health. Science of the Total Environment, 699, 134330.

Meharg, A. A., \& Zhao, F. J. (2012). Arsenic \& rice. Springer Science \& Business Media.

Mochizuki, Hitoshi. (2019). Arsenic neurotoxicity in humans. International journal of molecular sciences 20(14), 3418.

Nickson, R. T., McArthur, J. M., Ravenscroft, P., Burgess, W. G. and Ahmed, K. M. (2000). Mechanism of arsenic release to groundwater, Bangladesh and West Bengal. Applied Geochemistry, 15, 403-413.

Nurchi VM, Djordjevic AB, Crisponi G, Alexander J, Bjørklund G, Aaseth J. (2020). Arsenic toxicity: Molecular targets and therapeutic agents. Biomolecules, 10(2), 235.

399 Purkait, B. and Mukherjee, A. (2006). A statistical approach to correlate arsenic 400 contamination in groundwater with some related parameters - a case study from Malda 401 district, West Bengal, Eastern India.

402 Rahman, M. A., Hasegawa, H., Rahman, M. M., Rahman, M. A., \& Miah, M. A. M. (2007). 403 Accumulation of arsenic in tissues of rice plant (Oryza sativa L.) and its distribution in 404 fractions of rice grain. Chemosphere, 69(6), 942-948. 
405 Rahman, S., Sinha, A.C., Pati, R., Mukhopadhyay, D., 2013. Arsenic contamination: a 406 potential hazard to the affected areas of West Bengal, India. Environ. Geochem. Health 35, 407 119-132.

408 Sanyal S. K., Gupta, S. K., Kukal, S. S. and Jeevan Rao, K. (2015). Soil degradation, 409 pollution and amelioration. In: State of Indian Agriculture-Soil (H. Pathak, S. K. Sanyal and 410 P. N. Takkar, Eds.), National Academy ofAgricultural Sciences, New Delhi, pp. 234-266.

411 Singh J, Upadhyay SK, Pathak RK, Gupta V (2011) Accumulation of heavy metals in soil 412 and paddy crop (Oryza sativa), irrigated with water of Ramgarh Lake, Gorakhpur, UP, 413 India. Toxicological \& Environmental Chemistry 93(3): 462-473.

414 Smedley PL, Kinniburgh DG (2002). A review of the source, behaviour and distribution of 415 arsenic in natural waters. Applied Geochemistry 17:517-568.

416 Williams PN, Islam MR, Adomako EE, Raab A, Hossain SA, Zhu YG, Feldmann J, Meharg 417 AA (2006) Increase in Rice Grain Arsenic for Regions of Bangladesh Irrigating Paddies with 418 Elevated Arsenic in Groundwaters. Environmental Science \&Technology, 40 (16): 49034194908.

$420 \mathrm{Xu}$ XY, Mcgrath SP, Meharg AA, Zhao FJ (2008). Growing rice aerobically markedly 421 decreases arsenic accumulation. Environ. Sci. Technol 42:5574-9. 
Table 1: Initial properties of irrigation water and soil of selected blocks of Maldah district of West Bengal

\begin{tabular}{|c|c|c|c|c|c|c|c|c|c|c|}
\hline \multirow{3}{*}{$\begin{array}{l}\text { Blocks } \\
(n=20)\end{array}$} & \multicolumn{4}{|c|}{ Irrigation water } & \multicolumn{6}{|l|}{ Soil } \\
\hline & \multicolumn{2}{|l|}{$\mathrm{pH}$} & \multicolumn{2}{|l|}{$\mathrm{EC}\left(\mathrm{dS} \mathrm{m} \mathrm{m}^{-1}\right)$} & \multicolumn{2}{|l|}{$\mathrm{pH}$} & \multicolumn{2}{|l|}{$\mathrm{EC}\left(\mathrm{dS} \mathrm{m} \mathrm{m}^{-1}\right)$} & \multicolumn{2}{|c|}{ Organic carbon $(\%)$} \\
\hline & Mean \pm SD & Range & Mean \pm SD & Range & Mean \pm SD & Range & Mean \pm SD & Range & Mean \pm SD & Range \\
\hline Ratua I & $7.5 \pm 0.017$ & $7.02-7.78$ & $1.2 \pm 0.05$ & $0.53-1.45$ & $6.68 \pm 0.666$ & $6.12-7.34$ & $0.19 \pm 0.008$ & $0.15-0.22$ & $1.02 \pm 0.107$ & $0.82-1.23$ \\
\hline Manikchak & $6.8 \pm 0.01$ & $7.35-7.02$ & $0.96 \pm 0.04$ & $0.34-1.12$ & $6.88 \pm 0.277$ & $6.38-7.29$ & $0.28 \pm 0.015$ & $0.17-0.37$ & $0.96 \pm 0.161$ & $0.67-1.28$ \\
\hline Kaliachak I & $7.3 \pm 0.003$ & $6.98-7.42$ & $0.71 \pm 0.1$ & $0.34-0.89$ & $6.65 \pm 0.267$ & $6.34-7.25$ & $0.19 \pm 0.022$ & $0.11-0.27$ & $0.98 \pm 0.165$ & $0.56-1.13$ \\
\hline Kaliachak II & $7.9 \pm 0.061$ & $7.02-8.19$ & $0.53 \pm 0.09$ & $0.46-0.76$ & $6.45 \pm 0.663$ & $6.22-6.98$ & $0.14 \pm 0.029$ & $0.11-0.21$ & $1.12 \pm 0.129$ & $0.89-1.31$ \\
\hline Kaliachak III & $6.4 \pm 0.012$ & $6.28-7.01$ & $0.45 \pm 0.09$ & $0.31-0.51$ & $6.67 \pm 0.468$ & $6.41-7.07$ & $0.32 \pm 0.036$ & $0.24-0.41$ & $0.97 \pm 0.172$ & $0.56-1.16$ \\
\hline
\end{tabular}

429

430

431

432

433

434

435

436

437

438

439

440 
442 Table 2: Concentrations of arsenic in irrigation water, soil and tissues of rice plant in the five blocks of Maldah district

443

\begin{tabular}{|c|c|c|c|c|c|c|c|c|c|c|}
\hline \multirow{3}{*}{ Blocks $(n=20)$} & \multicolumn{10}{|c|}{ Concentrations of arsenic $\left(\mathrm{mg} \mathrm{kg}^{-1}\right)$} \\
\hline & \multicolumn{2}{|c|}{ Irrigation water $\left(\mathrm{mg} \mathrm{L}^{-1}\right)$} & \multicolumn{2}{|l|}{ Soil } & \multicolumn{2}{|l|}{ Root } & \multicolumn{2}{|l|}{ Straw } & \multicolumn{2}{|l|}{ Grain } \\
\hline & Mean \pm SD & Range & Mean $\pm \mathrm{SD}$ & Range & Mean \pm SD & Range & Mean \pm SD & Range & Mean \pm SD & Range \\
\hline Ratua I & $0.093 \pm 0.10$ & $0.01-0.48$ & $3.03 \pm 0.03$ & $0.50-5.90$ & $7.56 \pm 3.88$ & $3.11-15.14$ & $1.25 \pm 1.50$ & $0.15-4.32$ & $0.19 \pm 0.029$ & $0.03-0.59$ \\
\hline Manikchak & $0.553 \pm 0.17$ & $0.02-0.79$ & $3.24 \pm 0.81$ & $1.18-4.98$ & $11.93 \pm 7.34$ & $2.82-24.01$ & $1.68 \pm 0.97$ & $0.30-3.38$ & $0.43 \pm 0.022$ & $0.08-0.79$ \\
\hline Kaliachak I & $0.207 \pm 0.19$ & $0.01-0.48$ & $2.64 \pm 0.021$ & $0.94-4.13$ & $13.03 \pm 8.08$ & $3.03-25.98$ & $2.08 \pm 0.46$ & $1.14-2.91$ & $0.33 \pm 0.010$ & $0.20-0.52$ \\
\hline Kaliachak II & $0.449 \pm 0.15$ & $0.01-0.52$ & $2.54 \pm 0.97$ & $0.94-4.19$ & $11.06 \pm 6.29$ & $3.10-26.61$ & $2.10 \pm 0.93$ & $0.52-3.98$ & $0.34 \pm 0.010$ & $0.12-0.48$ \\
\hline Kaliachak III & $0.528 \pm 0.20$ & $0.03-0.74$ & $2.81 \pm 0.28$ & $0.28-4.22$ & $12.22 \pm 5.81$ & $3.89-28.21$ & $2.18 \pm 1.07$ & $0.91-4.95$ & $0.45 \pm 0.08$ & $0.14-0.61$ \\
\hline
\end{tabular}


445 Table 3: Biological accumulation factor (BAF), Translocation factor (TF) and Hazardous

446 Quotient (HQ) of arsenic in the rice varieties cultivated in the five blocks of Maldah district

\begin{tabular}{llllll}
\hline \multirow{2}{*}{ Block $(\mathrm{n}=20)$} & BAF & & \multicolumn{3}{c}{ Translocation factor (TF) } \\
\cline { 2 - 6 } & soil to root & soil to straw & soil to grain & root to straw & straw to grain \\
\hline Ratua I & 3.11 & 0.34 & 0.05 & 0.12 & 0.18 \\
Manikchak & 3.11 & 0.19 & 0.05 & 0.15 & 0.27 \\
Kaliachak I & 2.55 & 0.40 & 0.07 & 0.21 & 0.16 \\
Kaliachak II & 1.49 & 0.30 & 0.05 & 0.26 & 0.19 \\
Kaliachak III & 1.68 & 0.31 & 0.06 & 0.18 & 0.25 \\
\hline Mean \pm SD & $2.3 \pm 0.77$ & $0.30 \pm 0.07$ & $0.56 \pm 0.008$ & $0.184 \pm 0.054$ & $0.21 \pm 0.04$ \\
\hline Range & $1.49-3.11$ & $0.19-0.40$ & $0.05-0.07$ & 0.120 .26 & $0.16-0.27$ \\
\hline
\end{tabular}

449

450

451

452

453

454

455

456

457

458

459

460

461 


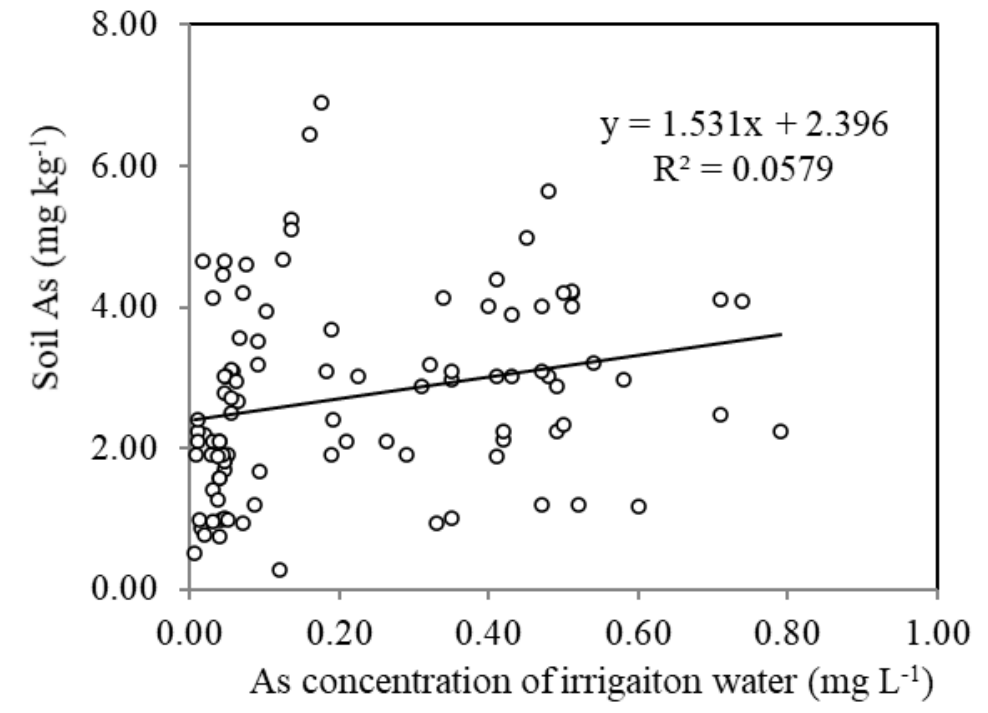

Fig. 2a. As in irrigation water vs Soil As

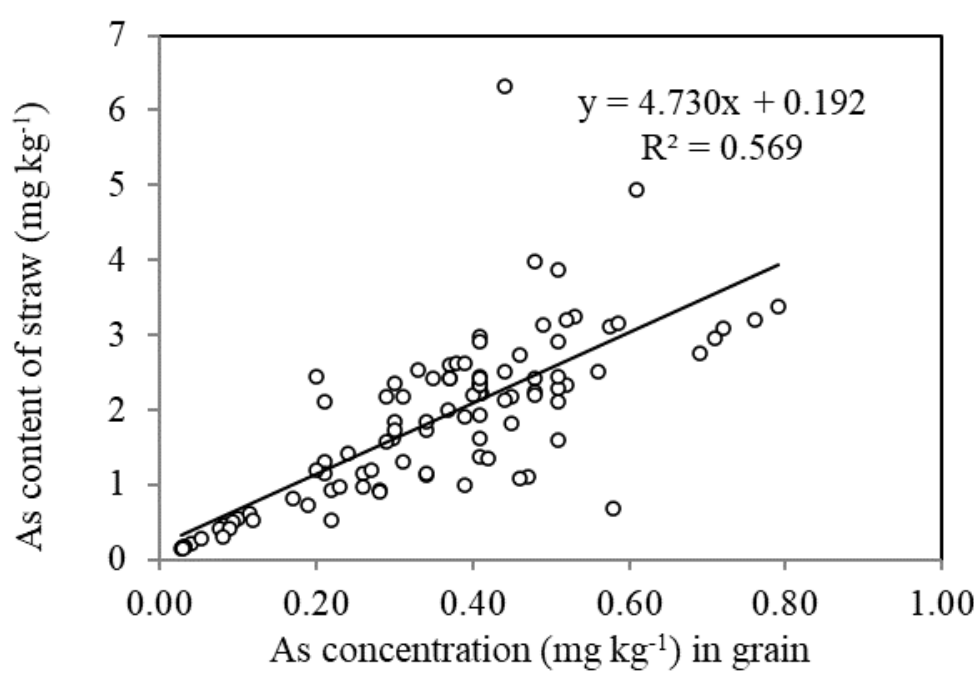

Fig. 2c. Grain As vs Straw As

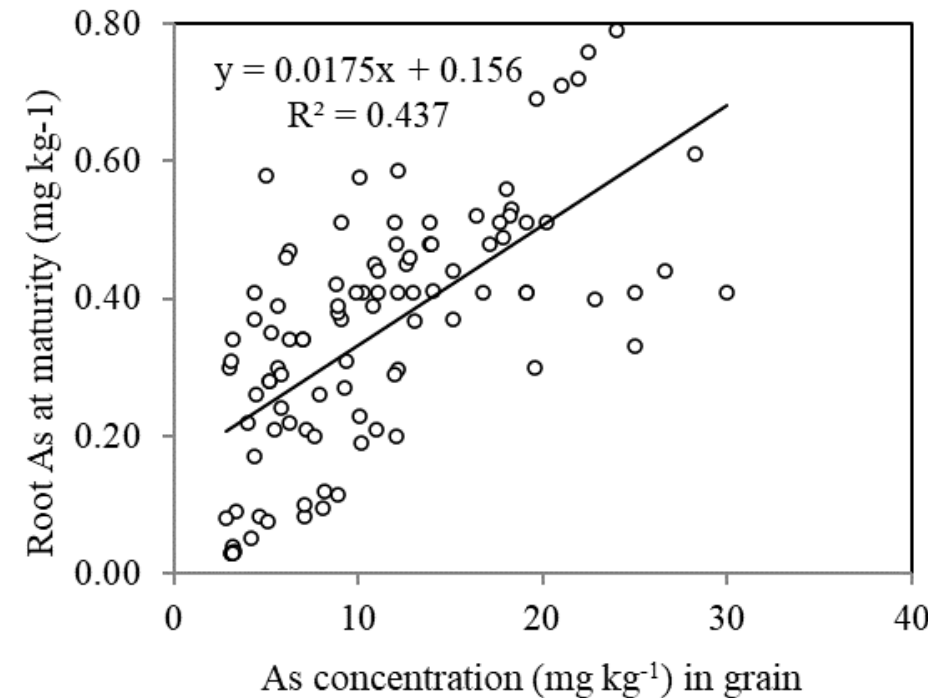

Fig.2b. Grain As vs Root As at maturity

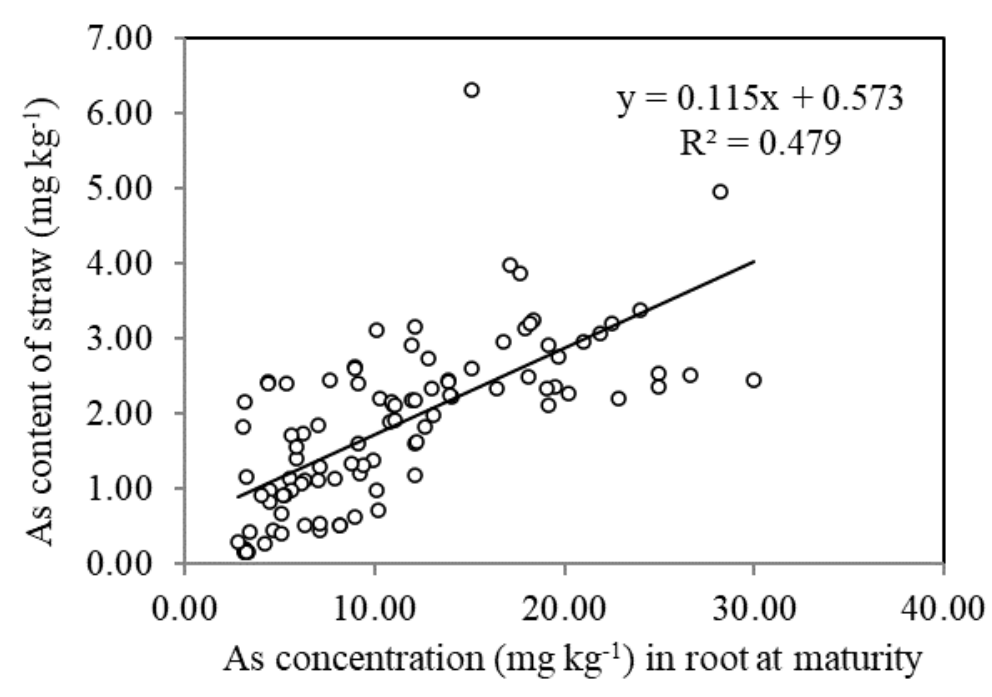

Fig.2d. Root As vs Straw As at maturity

Fig. 2 a-d. Interrelationship in-between As concentration of different plant parts of rice at maturity 


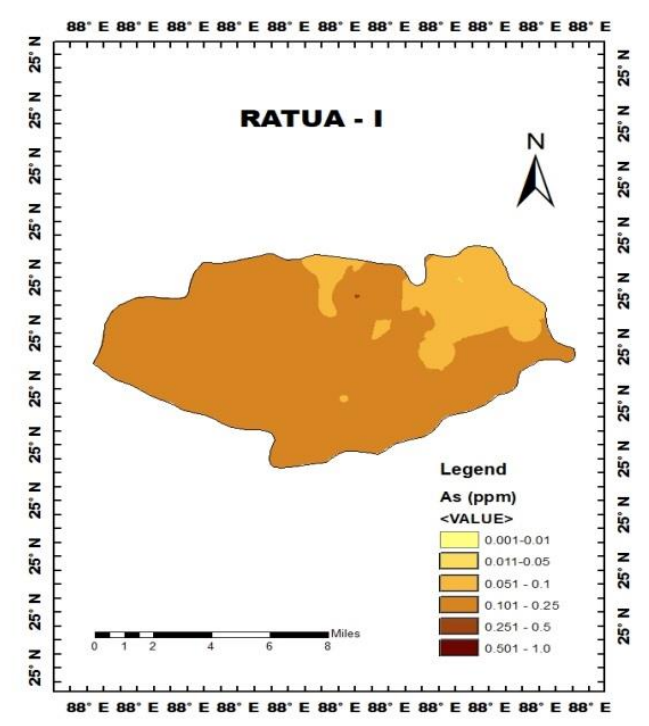

Fig.3a

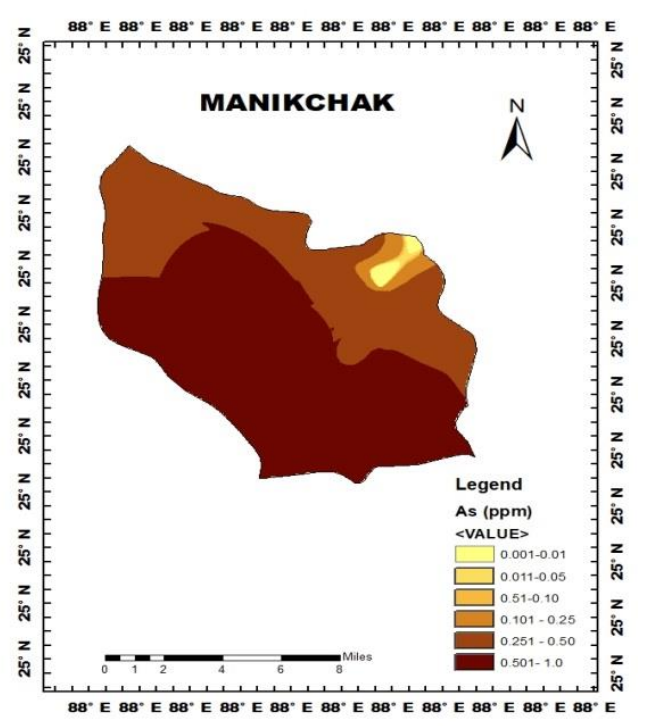

Fig.3b

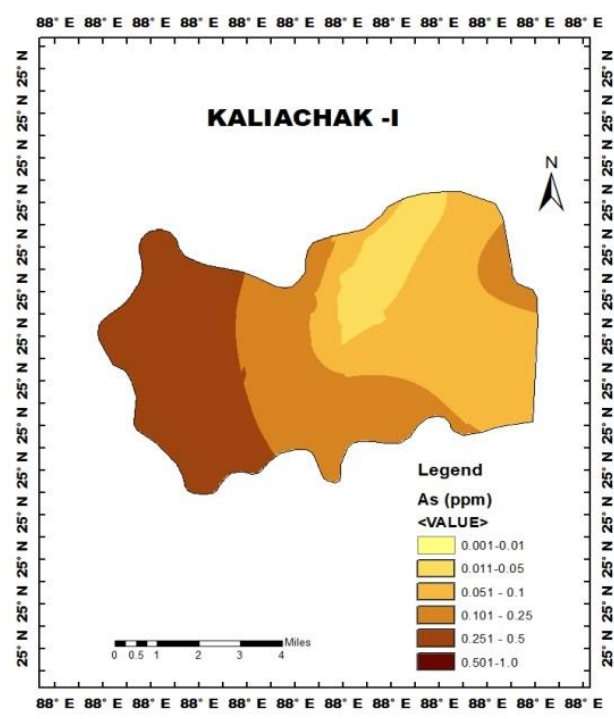

Fig.3c

477

478

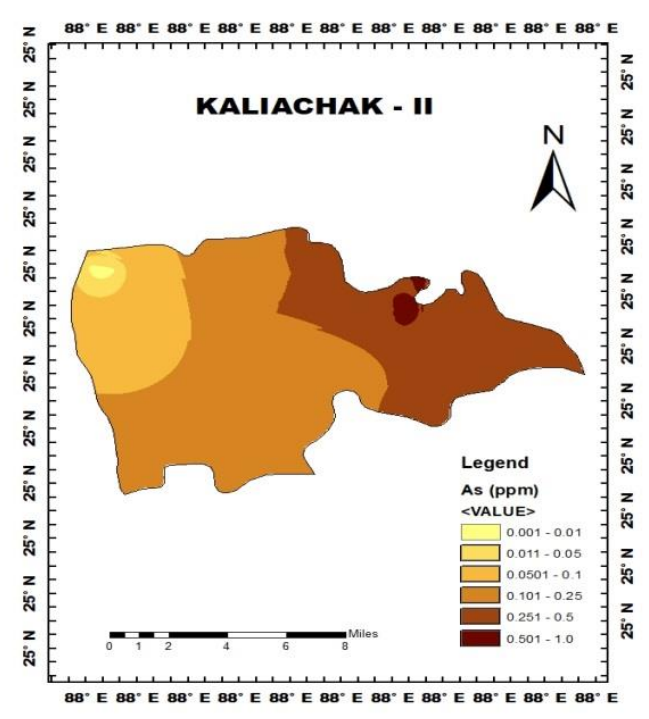

Fig.3d

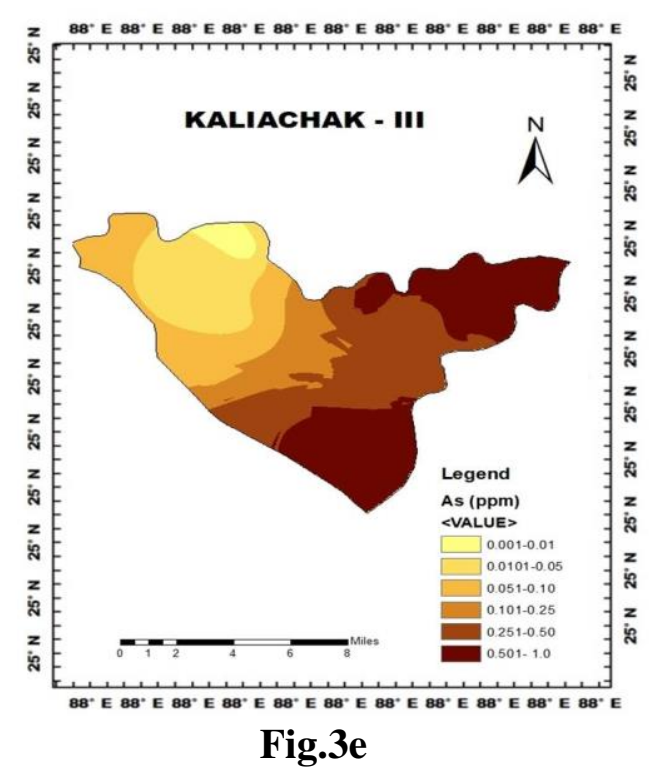

Fig.3a-e : Spatial distribution Maps showing As of irrigation water $\left(\mathrm{mg} \mathrm{L}^{-1}\right)$ of different blocks of Maldah district 

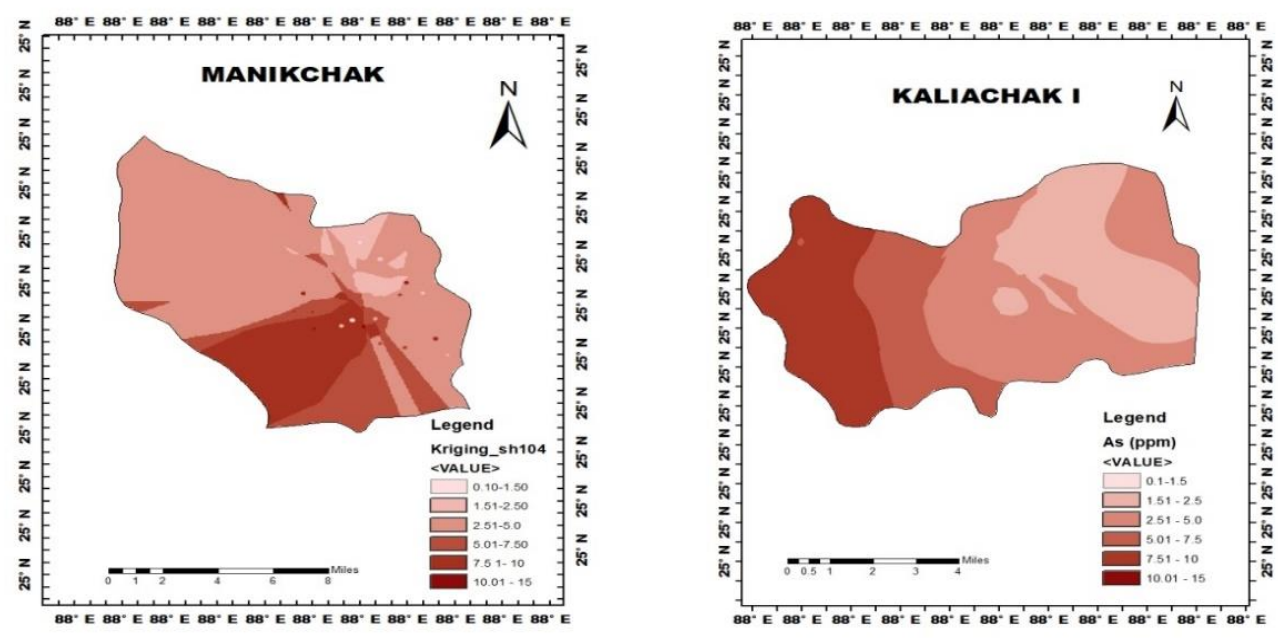

Fig.4b

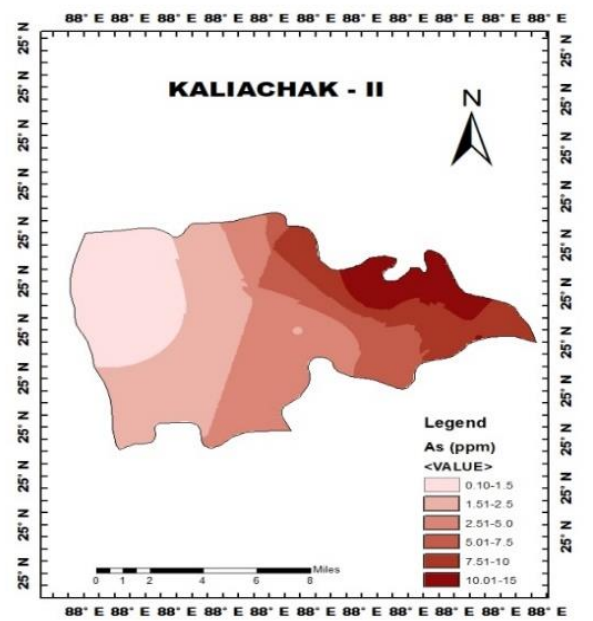

Fig.4d

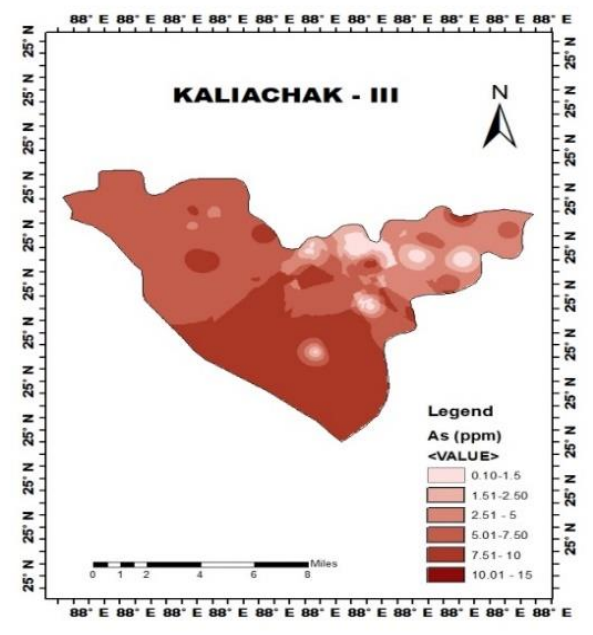

Fig.4e 


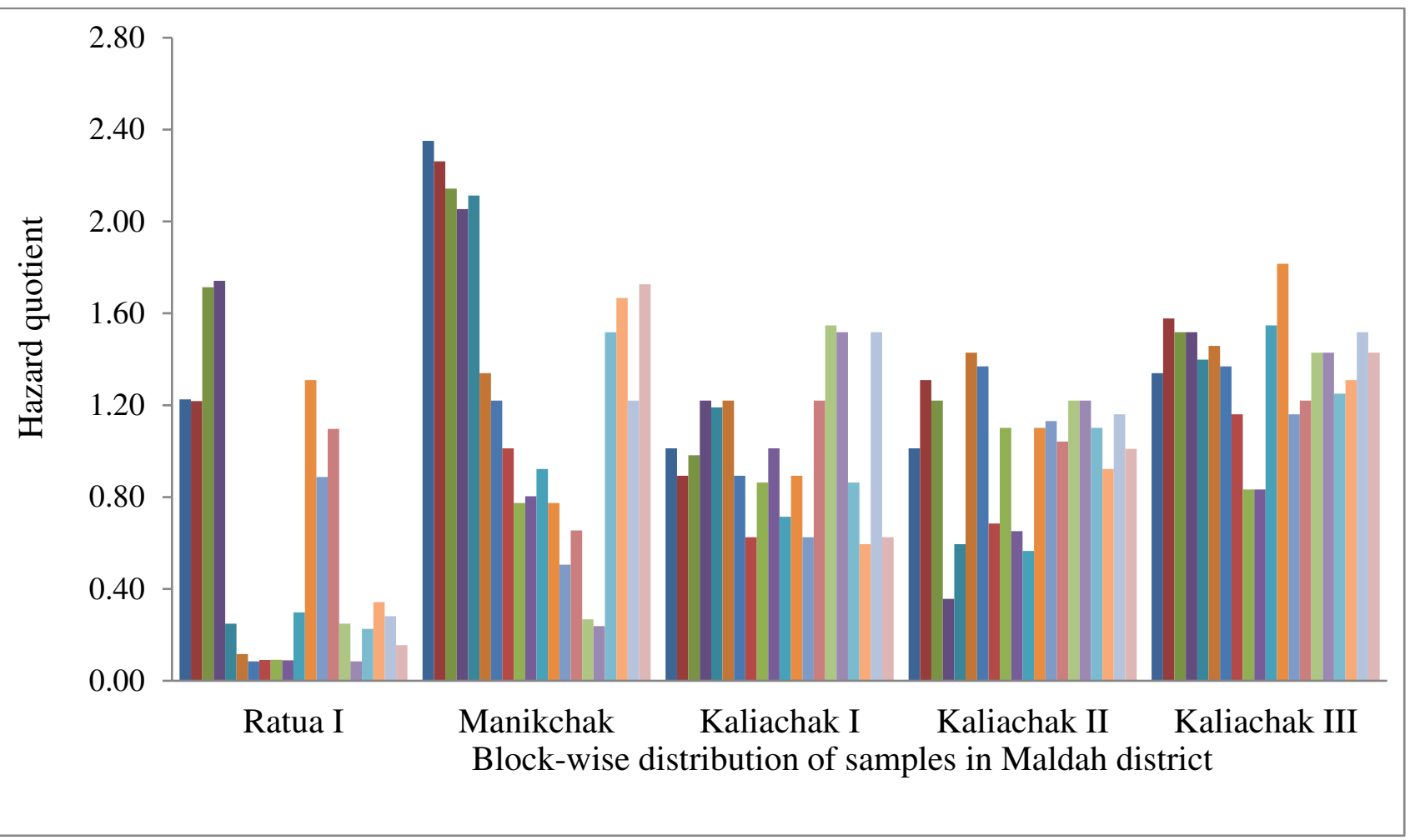

505

Fig.5. Block wise distribution of hazard coefficient in Maldah district

507

508

509

510

511

512

513

514

515

516

517

518

519

520

521 


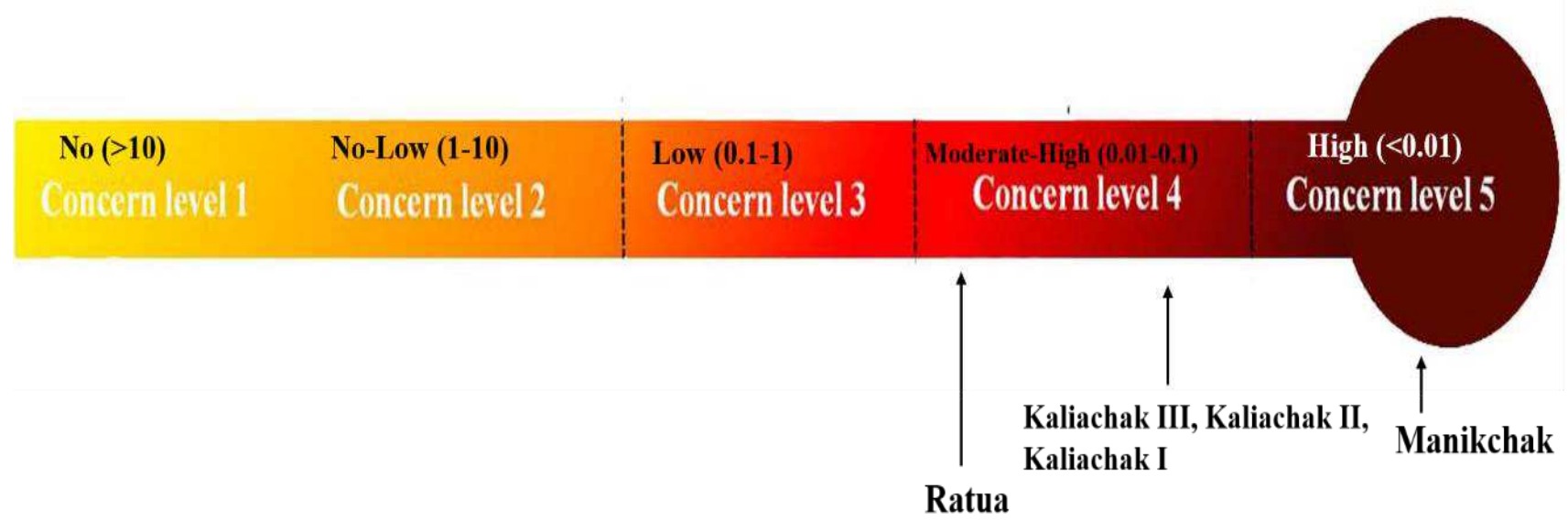

524

525

526

527

528

529

530

531

532

533

534

535

536

537

538

539

540

541

542

543

544

545
Fig 6: Risk thermometer scale showing the class of arsenic toxicity in selected blocks through consumption of locally grown rice 
547 Supplementary Table 1: Risk thermometer for As toxicity through consumption of locally grown 548 rice

\begin{tabular}{|c|c|c|c|}
\hline Blocks & Raw rice & ADI & SAMOE \\
\hline Ratua I & 0.115 & 0.8118 & 0.04 \\
\hline Manikchak & 0.262 & 1.8494 & 0.01 \\
\hline Kaliachak I & 0.194 & 1.3694 & 0.02 \\
\hline Kaliachak II & 0.201 & 1.4188 & 0.02 \\
\hline Kaliachak III & 0.233 & 1.6447 & 0.02 \\
\hline
\end{tabular}

549

550

551

552

553

554

555

556

557

558

559

560

561

562

563

564

565

566

567

568

569

570 
572 Supplementary Fig.1. Concentration of As in different parts of rice plants cultivated in the five 573 blocks of Maldah district

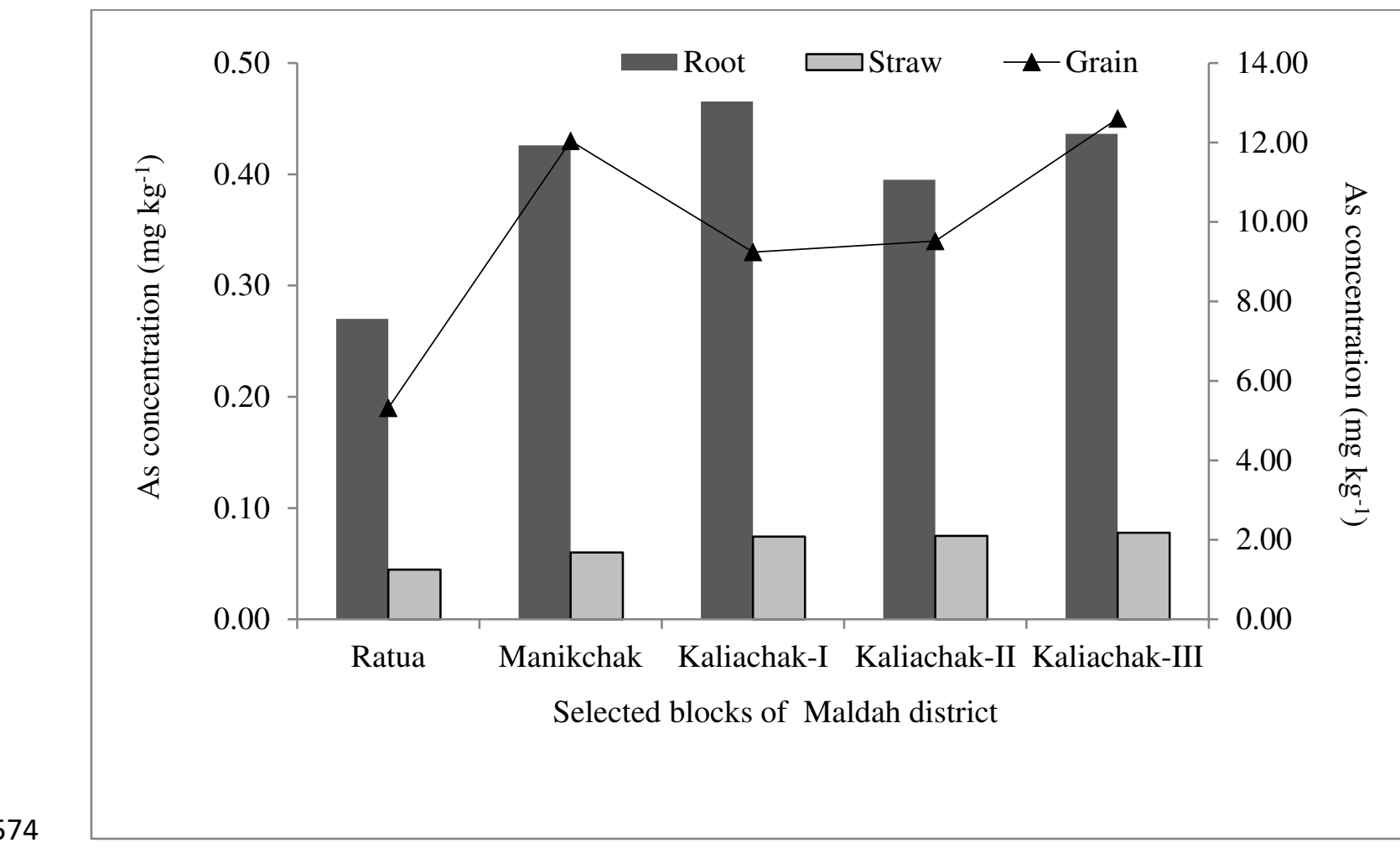

575

576

577

578

579

580

581

582

583

584

585

586

587

588 
Figures

\section{Image not available with this version}

Figure 1

Figure 1 


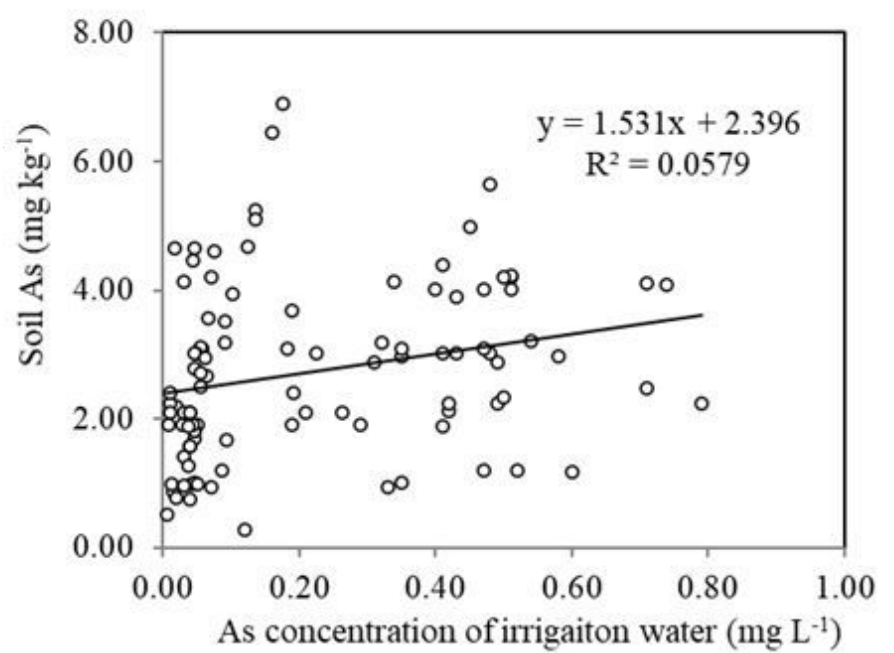

Fig. 2a. As in irrigation water vs Soil As

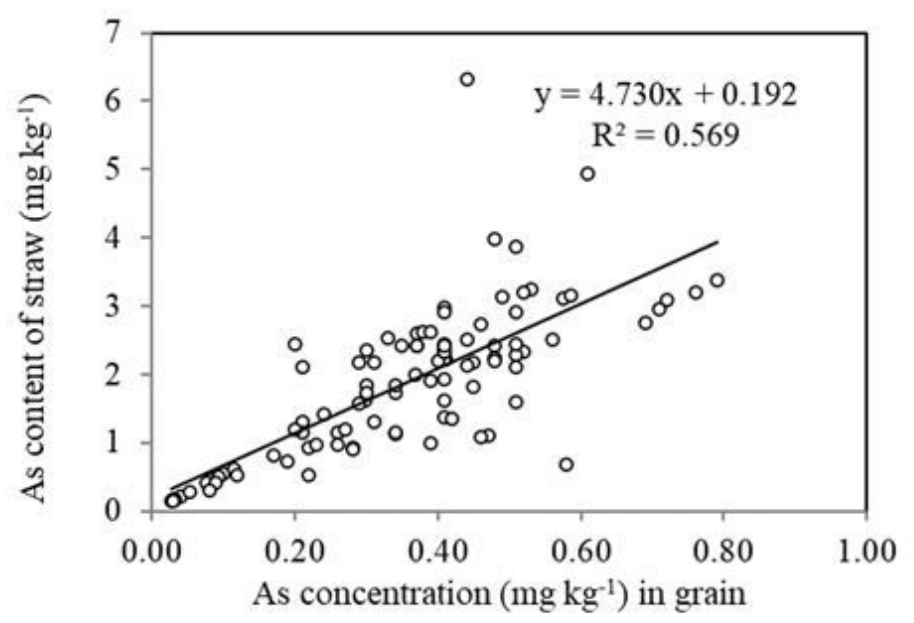

Fig. 2c. Grain As vs Straw As

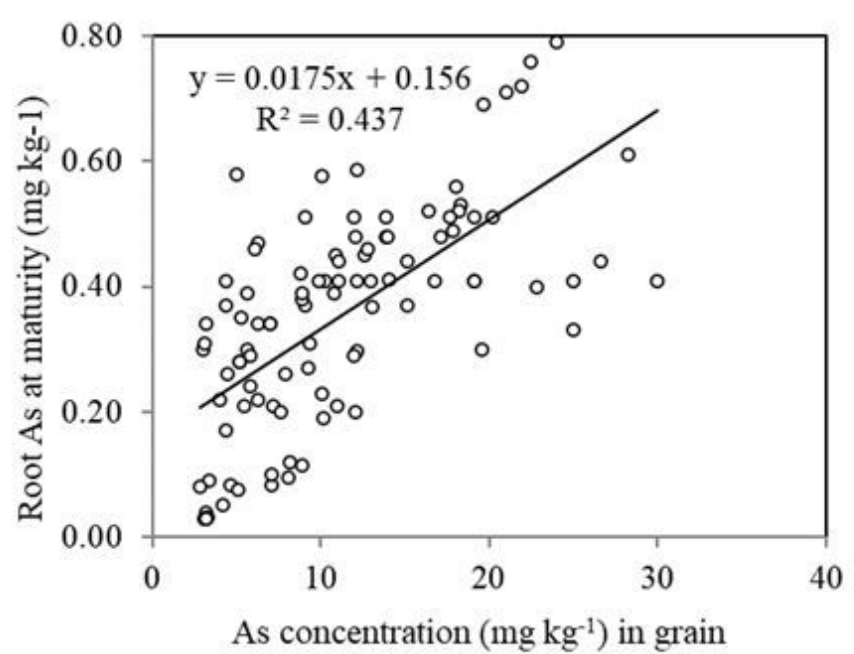

Fig.2b. Grain As vs Root As at maturity

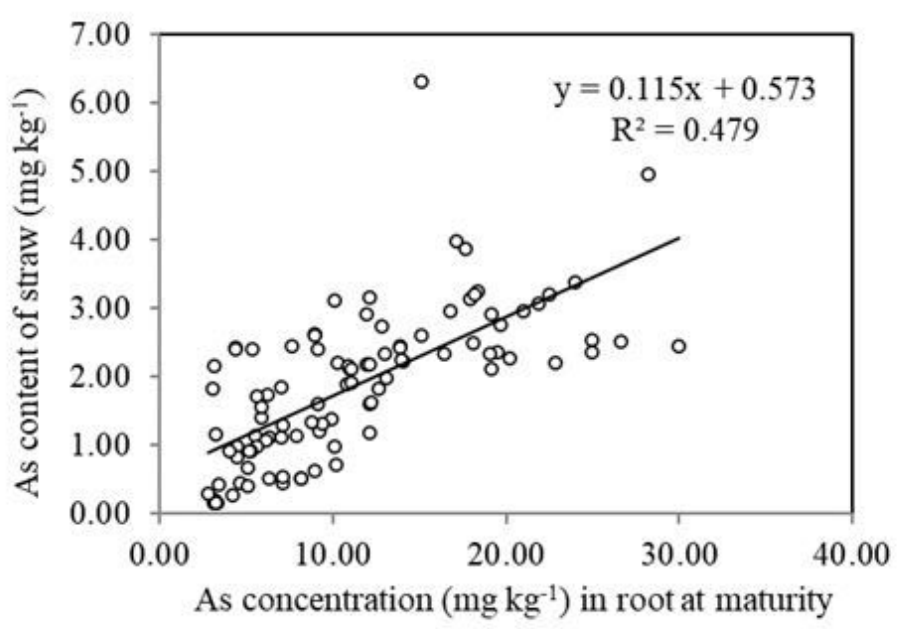

Fig.2d. Root As vs Straw As at maturity

\section{Figure 2}

a-d. Interrelationship in-between As concentration of different plant parts of rice at maturity 


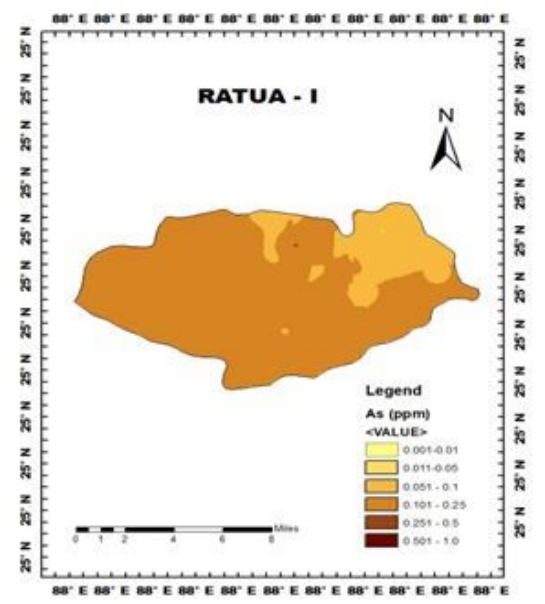

Fig.3a

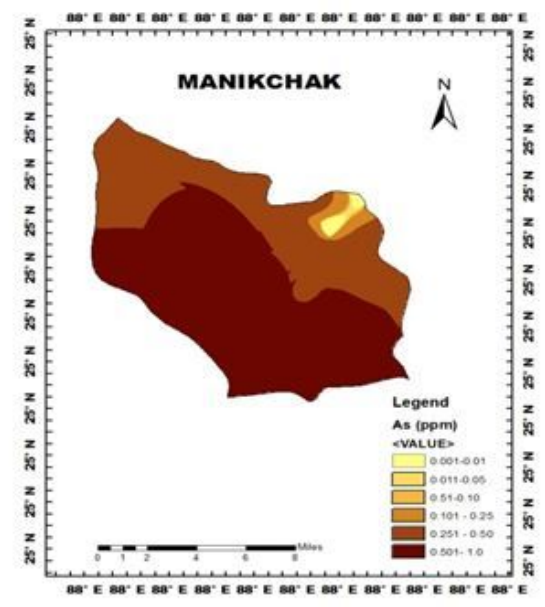

Fig.3b

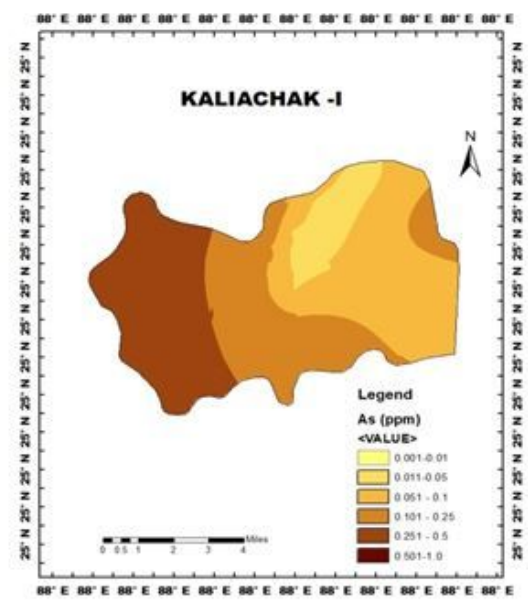

Fig.3c

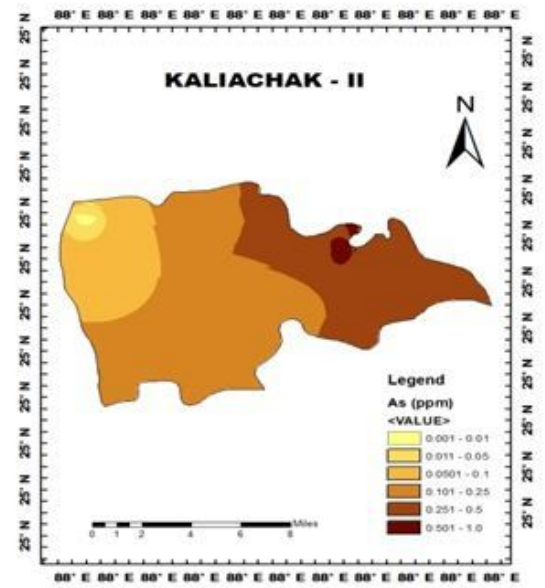

Fig.3d

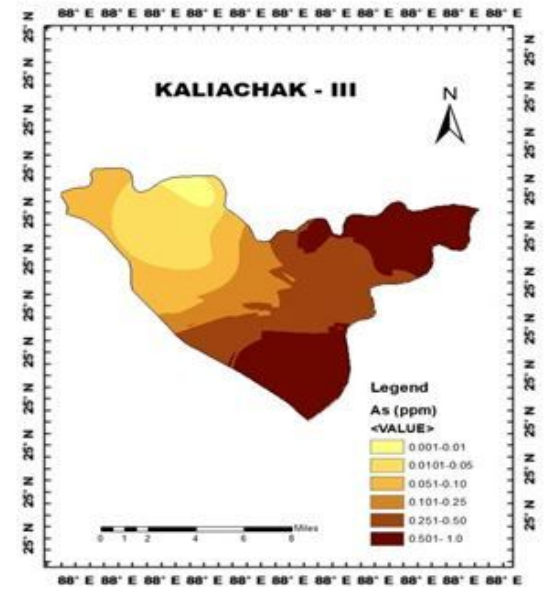

Fig.3e

\section{Figure 3}

a-e : Spatial distribution Maps showing As of irrigation water (mg L-1) of different blocks of Maldah district 


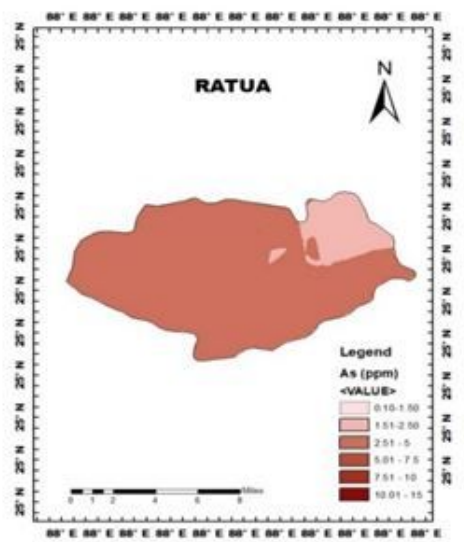

Fig.4a

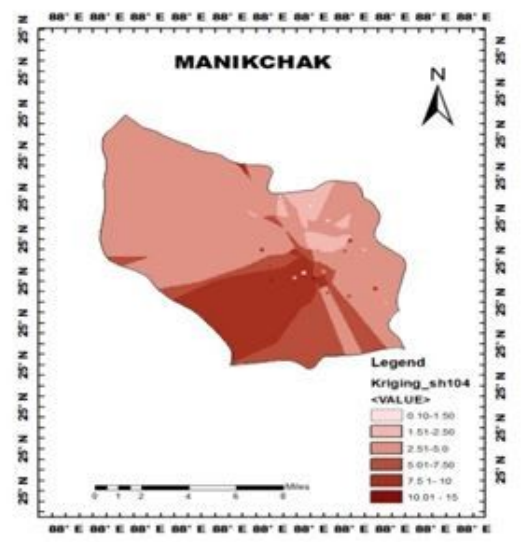

Fig.4b

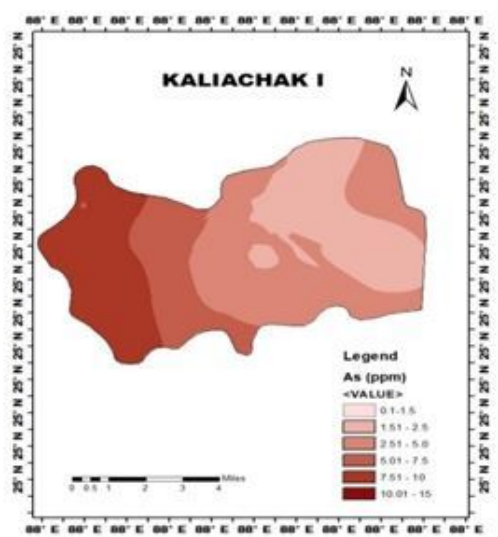

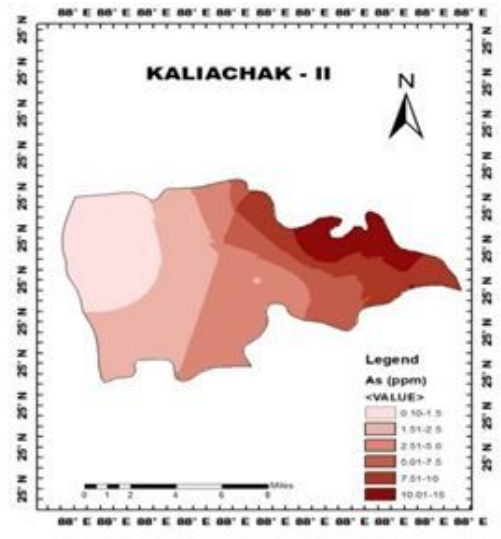

Fig.4d

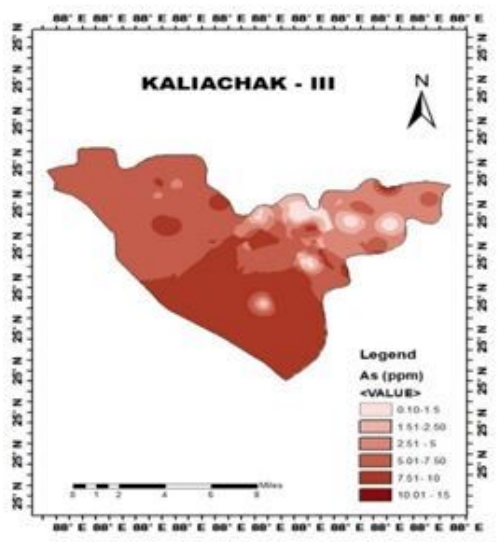

Fig.4e.

\section{Figure 4}

a-e : Spatial distribution Maps showing soil As (mg L-1) of different blocks of Maldah district 


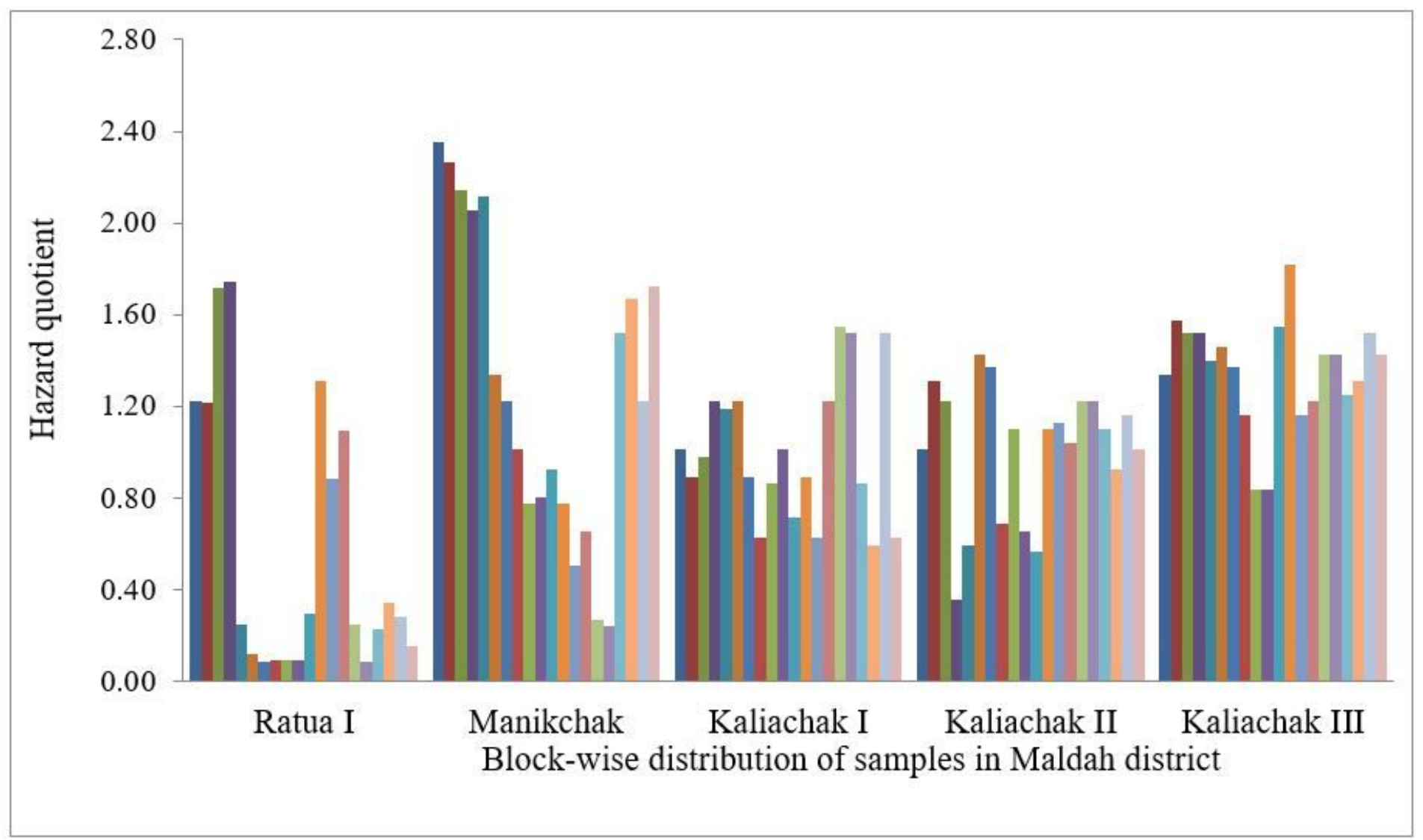

\section{Figure 5}

Block wise distribution of hazard coefficient in Maldah district

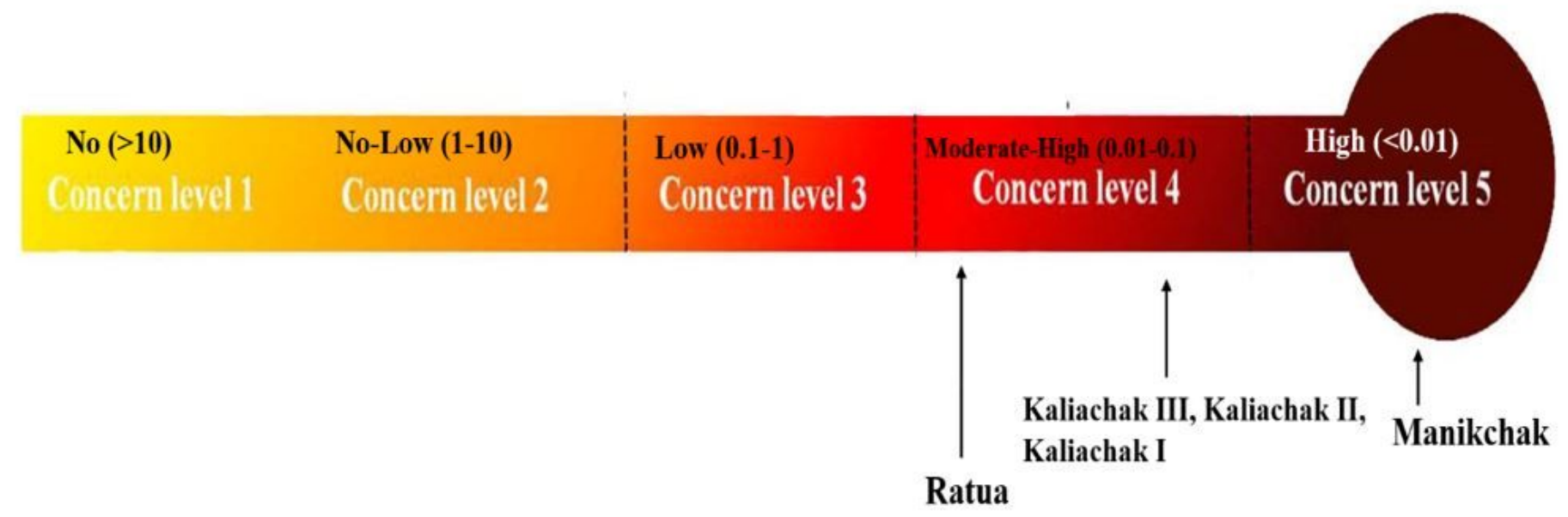

Figure 6

Risk thermometer scale showing the class of arsenic toxicity in selected blocks through consumption of locally grown rice 


\section{Supplementary Files}

This is a list of supplementary files associated with this preprint. Click to download.

- SupplementaryData.docx

- GraphicalAbstract.jpg 